\title{
Chapter 16 \\ The Turn of the Tide. Well-being \\ and Sustainability Around 1970
}

\author{
Frank Veraart and Harry Lintsen
}

\section{Contents}

16.1 Aldrin, Dieldrin, Eldrin en Telodrin: Blessing or a Shady Business?......................... 356

16.2 Synergetic Dynamics: Government, Citizens, Researchers and Entrepreneurs............ 357

16.2.1 Government - Makeable Well-being............................................................. 357

16.2.2 The Exalted 'Mid-Field'.................................................................................... 360

16.2.3 Research for Well-being.................................................................................. 363

16.2.4 The Linear Economy............................................................................. 364

16.3 The Monitor for 1970: Development of Well-being and Sustainability....................... 366

16.3.1 Perspective 1910: The Agenda at the Turn of the Century............................ 366

16.3.2 Perspective 1970: Environmental Problems in New Babylon......................... 369

16.3.3 The View from 2015-1970 as a Critical Watershed......................................... 370

16.3.4 The 1960s as the Great Transformation........................................................ 371

\begin{abstract}
Around 1970, welfare and economic growth became increasingly suspect. This chapter analyses and explains how this came about. It provides an inventory of the driving forces and institutional frameworks that shaped the development of well-being. In the period 1910-1970 the government energetically pursued the building of the welfare state. It was supported in this endeavour by a radically pillarised societal midfield. The economy was also under the tutelage of a dirigiste government. The six large Dutch multinationals generally supported the government's ambitions regarding the development of well-being. Characteristic for this period was the development of new patterns of consumption and a linear economy. Thanks to the mutual alignment among government, midfield and private enterprise it seemed possible to make well-being.

The monitor is used to evaluate the state of well-being around 1970 from three perspectives. Viewed from the perspective of 1910, the monitor shows how the original agenda was realised. But when viewed through the lens of the new societal visions of 1970, an entirely different image emerges. The increase in welfare had been achieved at the cost of serious environmental pollution and the loss of nature in both the Netherlands and elsewhere. The mounting criticism of the dark side of
\end{abstract}


well-being introduced a period in which ecology, natural resources, energy and climate change received emphatic attention (see Chaps. 17, 18, 19, 20, and 21). From the perspective of 2010 the situation had indeed become serious. In retrospect it appeared that around 1960 welfare, well-being and sustainability were most in balance.

Keywords Government $\cdot$ Midfield $\cdot$ Private enterprise $\cdot$ Welfare state $\cdot$ Linear economy $\cdot$ Monitor $\cdot$ Trade-off

\subsection{Aldrin, Dieldrin, Eldrin en Telodrin: Blessing or a Shady Business?}

In the Netherlands populations of various bird species (have) gone downhill at a tremendous rate. The decline of the sandwich terns on the island Griend from 40,000 pairs around 1955 to at present maximum 700 pairs is very likely partly due to serious pollution of the North Sea and the Wadden Sea with herbicides and pesticides... This pollution is mainly due to wastewater from chemical firms along the New Waterway...The feeding grounds of the sandwich terns are located a few hundred kilometers away from the factories that emit the poisonous wastewater. Nonetheless seaweed and plankton have been poisoned, and the fish that ate these organisms, and the birds that ate the fish. The 1962 Law on Herbicides and Pesticides that came into force in 1964 gives the government new possibilities to intervene... ${ }^{1}$

The Shell facility at Pernis, in the Rotterdam Harbour, was one of the world's foremost producers of pesticides. Its pesticides Aldrin, Dieldrin, Eldrin and Telodrin were held responsible for the massive bird mortality. In 1967 the toxicological division of the company invited the national press to a press-conference and a visit to the British Shell laboratory at Sittingbourne. In the conservative newspaper, De Telegraaf, Shell experts responded to the claims of what they called 'emotionally moved' alarmed individuals.

Today 12,000 people in the world will die of hunger... and over the entire year an estimated 1.3 million. That is an awful reality...The world is on the threshold of the biggest famine in her history...In order to feed the 6 billion inhabitants of this globe, three times more food has to be provided than is now produced...the yield of every square meter of arable land (must) be maximized to the fullest extent possible. And according to the insecticide experts this is only possible if the production of these pesticides - in the eyes of the public often regarded as shady substances - is significantly increased...Unfortunately several recent catastrophes - massive local bird mortality in England and Drenthe - have made the conservation-minded public wary and distrustful, which according to insecticide producers

\footnotetext{
${ }^{1}$ B. Bruins, 'We veranderen de wereld.. met chemische vergiften' in Het vrije volk: democratischsocialistisch dagblad (5-8-1967), 4.
} 
is lamentable because it is precisely the responsible substance Dieldrin, as well as Aldrin and DDT, that have over the course of years contributed so frightfully much to combating world hunger... And as far as bird mortality goes, however lamentable that may be, it pales into insignificance compared to the number of birds that are daily crushed by motorists on European highways. ${ }^{2}$

The debate between the critics of pesticides, who, following Rachel Carson, feared for the poisoning of humans and nature and the proponents from industry and agriculture was framed as the 'pesticide paradox.' It was presented as a dilemma of local environmental protection versus global food production, the offering that had to be brought to mitigate the famines in the world. In the background, of course, there were the interests of Shell, the significance of the agrarian sector, and jobs in the Netherlands.

Shell's charm-offensive was intended to temper the ever-growing criticism of environmental pollution. By the late 1960s Dutch industries were ever more insistently being held responsible for air and water pollution and the degradation of the environment. The 'pesticide paradox' was a typical outcome of vested ambitions and new choices in well-being by governments, the societal mid-field, firms and researchers. In this chapter we will first of all chart the different ambitions in their institutional contexts. After that we take a look at the monitor for 1970 . We look at which ambitions were realised, which new problems were articulated and who articulated the problems. Wat does this analysis portend for well-being and sustainability after 1970? New demands, concerns and norms informed new challenges. To conclude, we examine well-being in 1970 in the light of present-day norms. How rosy or how threatening was the situation?

\subsection{Synergetic Dynamics: Government, Citizens, Researchers and Entrepreneurs}

\subsubsection{Government-Makeable Well-being}

The First World War was in numerous respects the starting point for new institutional relationships in the Netherlands. Under pressure of the wartime situation, the political 'pacification' was achieved. Crucial disputes like universal suffrage were resolved and with the first general elections the relationships among the political parties were determined for many years. The confessional parties would long dominate both parliament and the government. The socialists and the liberals were constantly frustrated by their power. In the big cities the socialist parties also took part in local government. ${ }^{3}$

\footnotetext{
${ }^{2}$ A. Huguenot van der Linden, 'Landbouw legt het af tegen groei van wereldbevolking als gewas niet wordt beschermd' in De Telegraaf (29-07-1967). H.G.S. van Raalte was since 1964 employed at Shell's Toxological Division. S. Howarth and J. Jonker, Powering the Hydrocarbon Revolution, 1939-1973 (New York 2007), 401.

${ }^{3} \mathrm{P}$. de Rooy, Ons stipje op de waereldkaart: De politieke cultuur van modern Nederland (Amsterdam 2014), 151-73.
} 
The government, as it had for years in the past, pursued a welfare state. Economic growth was the basis of national well-being. In the nineteenth century, the government tried to encourage this by investing in infrastructure. This policy was continued into the twentieth century. The national government, province and municipalities all constructed roads. The provinces invested in provincial electrical networks. In the end the national government managed the telephone network et cetera. Education was also a domain in which various governments kept a finger in the pie and that began to consume a major part of the national budget in the twentieth century. A new phenomenon was the influence of the national government on flows of raw materials and on land-management. At the end of the nineteenth century it intervened in agriculture, founded the State Forest Service in 1899, underwrote the Hoogovens in 1920 and concerned itself with local conflicts around the mining of marl, gravel and clay. The national government developed an elaborate (but shifting) set of instruments to regulate and stabilize flows of raw materials and more generic economic processes.

Also new was the fact that the state, besides wanting to be a welfare state, now also had the ambition to become a 'caring-state.' That had already become visible prior to the First World War in its concern for the so-called 'social question.' It commiserated with the fate of the poor, the workers and the vulnerable ill with the Housing Law (1901), the Accident Law (1901) and the Invalidity Law (1913). These laws were followed by, among others, the Unemployment Act (1917), the Illness Law (1930), mandatory socialized health insurance (1941) and a series of laws passed after the Second World War: the Emergency Law Old Age Assistance (1946), followed 10 years later by the General Old Age Law (AOW), the General Widows and Orphans Law (1959) and the Unemployment Assistance Law (1964). The finale was the General Welfare Law that came into force in 1965. With this latter law the government absolutely replaced private initiatives in caring for the poor. Poor relief was no longer a question of charity; it now became a right and a duty for municipal governments to provide support. ${ }^{4}$ The 'caring state' had now definitively been founded.

Finally, the state had an age-old task in the domain of public works and, most crucially, water management. In the twentieth century this particularly Dutch aspect of well-being once again demanded important investments. The Zuiderzee Works (1918) and the Delta Works (1953) were the most impressive national projects. The provinces, water boards and municipalities also undertook a wide range of projects aimed at reducing the vulnerability of the Dutch delta.

The state's political ambitions were revealed in the formation of new ministries and the allocation of the government budget. In 1910 the ministry of Public Works, the ministry of Agriculture, Industry and Trade and the ministry of Internal Affairs were active in the expansion of well-being. The latter ministry included budgets for education, public health and social affairs. The costs of these ministries accounted for about $40 \%$ of the total government budget. This share grew to about $50 \%$ in the interbellum and again after 1960. In 1918 a new ministry of Education, Art and

${ }^{4}$ K. Schuyt and E. Taverne, 1950: Welvaart in zwart wit (Den Haag 2000), 288-306. 


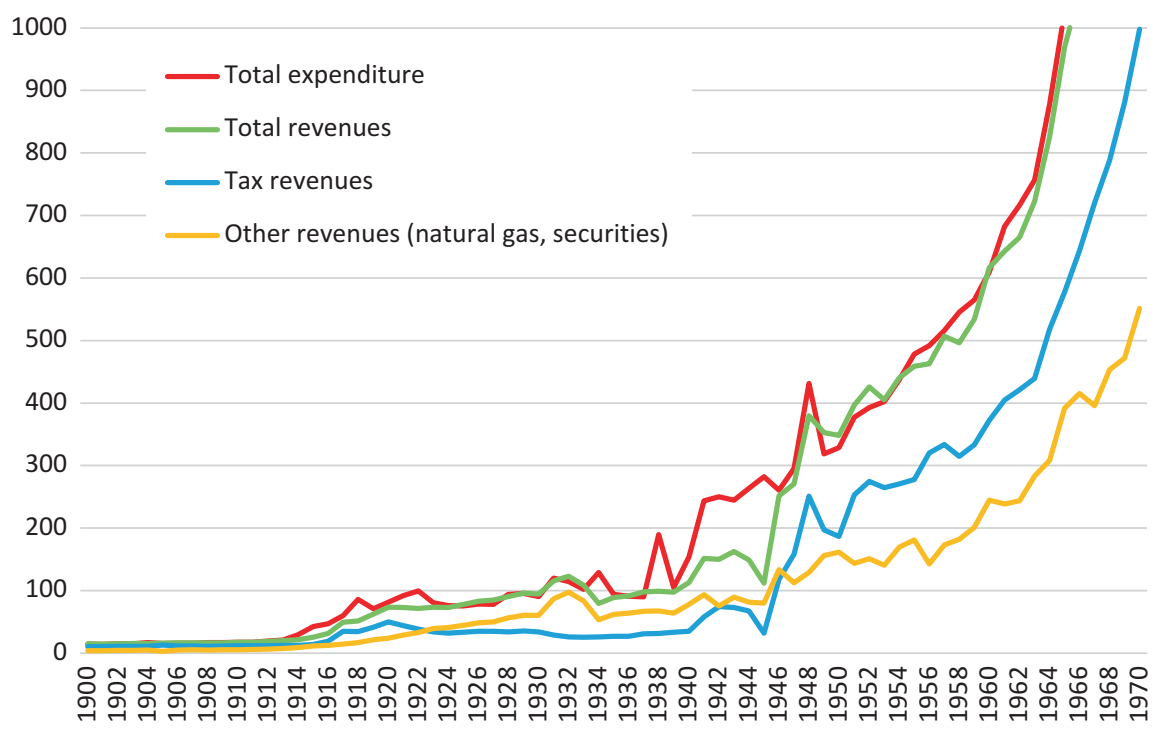

Graph 16.1 Government Finances, expenditures and income in euro per inhabitant, 1900-1970 Source: CBS - Rijksfinanciën vanaf 1900

Sciences was called into being. In that same year the ministry of Trade, Industry and Agriculture founded a department for Labour, which blossomed into the ministry of Social Affairs in 1933. After the Second World War the new ministries of Reconstruction and Public Housing, Transport and Public Works, and Agriculture, Fisheries and Food Supply underscored the new agenda of the Dutch government. In 1951 government dedication to public health crystallized in a new ministry of Social Affairs and Public Health.

Alongside the expansion of the governmental apparatus, budgets increased for policy domains like education, social affairs, infrastructure, public housing and public health. ${ }^{5}$ State expenditures increased from a few tens just after the First World War to nearly a hundred euros per inhabitant at the end of the 1930s. After the Second World War government spending again increased steadily (Graph 16.1). These expenditures also began to comprise an ever larger share of the national economy. The share of government spending in the national economy rose from less than $10 \%$ at the outset of the twentieth century to more than $40 \%$ around $1980 .{ }^{6}$

The steadily growing government intervention was partly the consequence of external crises. Two wars, the Great Depression, and reconstruction cleared the way for new perceptions of the role of government. But these perceptions required support among the population at large as well as among specific societal groups.

\footnotetext{
${ }^{5}$ Handelingen Tweede Kamer, 'Nota betreffende den toestand van 's lands financiën' 20 september 1920. Via www.rijksbegroting.nl/algemeen/rijksbegroting/archief (1910).

${ }^{6}$ J.L. van Zanden en R.T. Griffiths, Economische geschiedenis van Nederland in de twintigste eeuw (Utrecht 1989), 61.
} 
Hence, after the Second World War there was clear social support for a dirigiste role for government. The first questionnaires circulated by the Netherlands Institute for Public Opinion (NIPO), founded in 1946, included the question 'What should the government tackle first?' The results showed that according to the population, the government should take the lead in seeing to it that primary needs were met: food, housing and sufficient income. ${ }^{7}$ But even more important was support from specific social groups and associations. These articulated social needs, represented their constituencies in politics and possessed the means to exert influence. It then appears that the solid anchoring of politics and the government in the 'societal midfield' was decisive for the success of government policy with respect to wellbeing. But in precisely that anchorage lay the seeds of new problems around wellbeing and sustainability.

\subsubsection{The Exalted 'Mid-Field'}

In the period between 1910 and 1970 the 'societal midfield,' the complex of nongovernmental associations based on shared interests and religious convictions, became increasingly densely populated. Confessional groups as well as socialists organised themselves in countless organizations and institutions. Thanks to their supremacy at national and municipal levels they were able to direct significant subsidies to their own organizations; this enabled them to engage in all kinds of social services: aid to the poor, the construction of public housing, public health and education. Though it was true that the Welfare Law of 1965 had compelled confessional groups to surrender their dominance in the fight against poverty to municipalities, other aspects of well-being surfaced in its stead. There were short and direct connections to the political parties. Pressure on the government and the public administration was severe. The pillarised mid-field co-authored the legal framework for well-being or lent its support to such efforts. It was also able to influence what was to count as well-being.

It should not be supposed, however, that the mid-field was composed only of the 'pillars.' Quite the contrary. The economic domain, for example, was also populated by a variety of branch organisations. ${ }^{8}$ During the first half of the nineteenth century the Netherlands had seen the rise of a number of agricultural organizations. These would become more numerous (in part via the fragmenting effects of the pillars), would dissolve into a network of governmental organisations, knowledge institutes and enterprises and in this way eventually come to be known as the 'green front.' Toward the end of the nineteenth century, other economic domains sprouted interest

\footnotetext{
${ }^{7}$ The Netherlands Institute for Public Opinion (NIPO) was founded in 1946, with the aim of collecting information on opinions among the populace as an aid to government. J.C.H Blom, Crisis, bezetting en herstel: Tien studies over Nederland, 1930-1950 (Rotterdam 1989), 184-90.

${ }^{8}$ B. Bouwens and J. Dankers, Tussen concurrentie en concentratie. Belangenorganisaties, kartels, fusies en overnames (Amsterdam 2010), 54-57.
} 
and lobby groups of building contractors, butchers, bakers, carpenters and other 'petit-bourgeois' groups. These began locally and were often the basis for national, partly pillarised, organisations. During the First World War they became more numerous. In 1907 the ministry of Agriculture, Industry and Trade counted 35 national and 307 local organisations. After the war their number increased to no less than 337 national and 1329 local organisations. They were in the first place interest groups of entrepreneurs seeking to limit competition among themselves, to offer courses to their members, to exchange information about innovation and to lobby the government. But they were also harnessed to help solve the social problems of their time. During the First World War, for example, the national government worked closely with the Bakers' Union and the Station for Milling and Baking that the latter had founded. Due to the flour shortage, they had to formulate norms for so-called government wheat, search for flour substitutes and develop alternative recipes for baking bread. ${ }^{9}$ In this way branch organisations became involved in food quality, housing construction, working conditions and so on. Increasingly they formed a portal for welfare legislation and set themselves up as essential links and consultation bureaus. They also began to play an active role in industrialisation policy after the Second World War. ${ }^{10}$

In addition, the mid-field also sported an increasing number of professional societies that also felt compelled to take some stand on well-being. Accountants, sociologists, home economists, electrical engineers and other professionals organized themselves in the first half of the twentieth century around new academic programs of study. Their professions were extremely dynamic and in search of social and academic recognition. At the end of the nineteenth century, engineers had already shown how that could be done. The members of the Association of Civil (later Delft) Engineers participated in the debate on the 'social question' and loudly proclaimed the relevance of their profession in finding solutions. They did the same in the course of the debates during the interbellum on the rationalisation of the economy and the firm. ${ }^{11}$ They argued that this would provide advantages for the entrepreneur, the worker and national welfare. Together with accountants and psychologists, engineers were the shock troops of the rationalisation movement. The movement itself was broader and included politicians, entrepreneurs, leading cadres, civil servants, and advisors. They came together in large numbers for the first time at the Economising (Efficiency)-Congress in Amsterdam in 1923 and organised themselves in the Netherlands Institute for Efficiency, the NIVE. Professionals did not exert their influence on politics and policy by way of the pillars, as did the confessionals and socialists, but via these kinds of networks. The networks of congress organisations, knowledge institutes and laboratories were interwoven with ministries, provincial services and municipal organisations.

\footnotetext{
${ }^{9}$ M. Davids, H.W. Lintsen, and A. van Rooij, Innovatie en kennisinfrastructuur: Vele wegen naar vernieuwing, vol. 5, Bedrijfsleven in Nederland in de Twintigste Eeuw (Amsterdam 2013), 75-76.

${ }^{10}$ Bouwens and Dankers, Tussen concurrentie en concentratie, 158-159.

${ }^{11}$ H.W. Lintsen, Made in Holland: Een techniekgeschiedenis van Nederland [1800-2000] (Zutphen 2005), 171-173.
} 
There was also a category of civil associations not associated with a pillar, economic sector or profession, like the tourist organisation ANWB (1883), the Association for the Preservation of Natural Monuments (1905), the Netherlands Association of Housewives (1912) and the Netherlands Consumer Union (1953). These too became more or less involved in defining and ameliorating the quality of life. The Netherlands Association of Housewives (NVVH), for example, first profiled itself as a think-tank for labour-saving solutions in the household. ${ }^{12}$ Together with liberal and socialist women's clubs they took the initiative in finding collective solutions for the more tedious aspects of housekeeping. There were, for example, experiments with putting the family laundry out to collective laundries and delegating cooking to collective kitchens. Special housing complexes were designed with collective facilities like a space for washing and drying, a bath-house, central heating, a central waste disposal chute or a central kitchen. These initiatives did not survive the experimental phase. In addition, the NVVH concerned itself with the quality of household work and household products. Their seal of approval for household products: 'Approved by the NVVH' was probably the best known of all. In essence the NVVH was still an old-fashioned status organisation, because it furthered the interests especially of middle-class 'petit bourgeois' women.

These civil associations had varying kinds of influence. The ANWB fought for highways and found strong partners in the Royal Institute of Engineers and the Rijkswaterstaat (the national public works agency). Hence the organisation was allowed a finger in the pie of the National Road Plan of 1928. Contrariwise, nature associations were hardly able to make a dent in the land consolidation projects that were carried out on a large scale. Nature conservation and environmental problems were neither big issues for the government nor in politics more generally. Despite this, the civil associations concerned with this issue did score regular, if small, successes. The occasion was more often than not a local problem that was taken up by a local interest group. In 1925, for example, the Natural History Society in Limburg protested against marl mining that threatened to consume the local hill, the Sint Pietersberg, a stance that led to the amendment of the permit. Similarly, protests against gravel dredging in Limburg led to the Excavation Law of 1965. Disquiet among Rotterdam's population concerning air pollution was articulated by the Association against Air Pollution in and around the New Waterway (1963) and the Committee for Habitability of the Waterway Region (1968). These organisations mobilized political pressure, resulting in the 1970 Law on Air Pollution. Nature conservation and environmental organisations had to look for support to the 'pillars,' that had access to the political parties, or to the professionals with their networks in the state apparatus. They were the part of the 'mid-field' that made the 'pillarised' and 'professional' Netherlands receptive to environmental issues and nature conservation and that paved the way for the big debate on sustainability that welled up at the end of the 1960s.

\footnotetext{
${ }^{12} \mathrm{R}$. Oldenziel, 'Het ontstaan van het moderne huishouden: toevalstreffers en valse starts, 1890 1918', in: J.W. Schot, H.W. Lintsen, A. Rip en A. Albert de la Bruhèze (eds.), Techniek in Nederland in de twintigste eeuw (Zutphen 2001), deel IV, 41-41.
} 


\subsubsection{Research for Well-being}

The 'professional' Netherlands, that is to say, the higher and academically educated part of the Dutch population with their professional associations, was tightly bound to the modern knowledge infrastructure whose foundations were laid in the First World War. We focus here on the laboratory, that became the icon of the production of innovations and well-being during the interbellum. The laboratory became the place where research was done on resources and materials and where experiments were performed on new products and processes. To be sure, innovations still originated on the work floor, in workshops, by dint of the efforts of inventive entrepreneurs and entrepreneurial inventors, but the laboratory was the modern route. As far as we know, there were at least 500 laboratories in the Netherlands around 1940, of which about $31 \%$ at the universities, 30\% in (semi-) government agencies, and $19 \%$ in industry. The rest was private or was run by an association or foundation. ${ }^{13}$ The 1932 founding of Netherlands Organization for Applied Scientific Research (TNO), the central government laboratories, was an important decision. After a difficult start, this organisation eventually developed into the biggest public research institute in the Netherlands. In 1965, TNO had four branches: the Industrial Organisation TNO, the Health Organisation TNO, the Nutrition Organisation TNO and the National Defence Organisation TNO with all told nearly 40 research institutes. ${ }^{14}$ The Industrial Organisation with 24 institutes was the biggest branch. TNO was a cooperative research organisation, an alliance among the government, industry and the 'professional' Netherlands. Ministerial functionaries, members of sectororganisations and researchers at the (technical) universities were well-represented in all the managerial and consultative organs of TNO. They drew up the collective research agendas. The government and industry financed the research.

Some of the laboratories were dedicated to research and development. This was especially the case for the industrial laboratories. These labs produced a stream of innovative prototypes, including electron tubes, margarines, radios, plastics, chemical insecticides and pesticides, industrial automatons and artificial fibres. The (semi-) governmental laboratories also contributed to this stream. For example, the agricultural test stations investigated the use of artificial fertilizer and the tillage of vegetables. TNO operated in numerous fields and among other things developed new plastics, analysed the behaviour of building constructions, searched for better vaccines and investigated conservation techniques. In addition to research and development the laboratories also dedicated themselves to the important task of testing and evaluating. They developed testing methods, designed standards of quality, collected data on the quality of raw materials, semi-finished products and endproducts and evaluated production processes and products.

The researchers contributed to paving the way for a modern economy, one in which the electro-technical and chemical industries were dominant and in which all

\footnotetext{
${ }^{13}$ Davids, Lintsen en Van Rooij, Innovatie en kennisinfrastructuur, 100-102.

${ }^{14}$ H.W. Lintsen (eds.), Tachtig jaar TNO (Delft 2012), 29.
} 
sectors were suffused with the new principles of efficiency and rationality. They were also partly the trailblazers of the consumer society and experimented with new services like the telephone and electricity as well as with an enormous potential in new consumer goods like vacuum cleaners, washing machines, electric irons, radios and plastic toys. Between the two world wars, parts of the middle class garnered experience with these new commodities. After the Second World War the new consumer goods became available to the masses.

The researchers were also deeply involved in aspects of well-being and the construction of the caring state. TNO made especially important contributions. The Industrial Organisation TNO investigated the quantitative aspects of public housing construction (rate of production, costs of production and labour productivity) as well as the qualitative aspects (problems with moisture, frost damage, thermal resistance etc.). ${ }^{15}$ The Health Organisation TNO worked on public health, for example the relation between personal health, housing, work and the environment (soil, water and air). ${ }^{16}$ The Nutrition Organization TNO analysed, among other topics, the main components of food like carbohydrates, proteins, vitamins, minerals, fats and fibres. The results were used to produce nutritional charts. ${ }^{17}$ Research and testing by TNO often led to norms for working conditions, housing quality, fire safety, food quality and food safety.

In the 1960s the researchers became ever more involved in environmental problems. Knowledge of air, soil and water pollution would in large measure come to shape the debate on environmental problems. New measuring instruments increased the accuracy with which it was possible to chart both old types of pollution and newly discovered ones. Politicians and policy-makers mobilized researchers to define problems, establish norms and provide solutions.

\subsubsection{The Linear Economy}

By the 1960s economic developments had finally ushered in the welfare state. That followed on several violent shocks: two world wars and an economic recession. After the Second World War, the economy stabilised and grew rapidly. Economic historians qualify the period as an economic wonder. It signified the definitive breakthrough of welfare for the vast majority of the population. Some see its origins in the favourable development of the world economy, the politics of planned wages, industrialisation policy and so on. But viewed over the long term we must conclude that it was a case of the crystallisation of an oversaturated solution. In the Netherlands, as in many West-European countries, the welfare state had been in the works for more than a half-century: technically, economically, politically and culturally. It was just

\footnotetext{
${ }^{15}$ Lintsen, Tachtig jaar TNO. (2012): 44.

${ }^{16}$ Lintsen, Tachtig jaar TNO. (2012): 133.

${ }^{17}$ Lintsen, Tachtig jaar TNO. (2012.: 144.
} 
a question of waiting for favourable economic circumstances to enable the entire structure to blossom - and these were certainly present in the 1960s.

In this period, the economy and society had a strongly corporatist bent. Netherlanders worked together in many fields in associations, foundations, councils and other public and private organs. Corporate bodies were present in agriculture, public housing and healthcare. Entrepreneurs cooperated in branch organisations. Cartels were important instruments in ordering markets and regulating competition. ${ }^{18}$ A corporatist tradition of consultations lay at the foundation of Collective Labour Agreements (CAOs) and the Social-Economic Council (SER). It was also visible in TNO's structure. The corporatist model (the polder or Rijnlands model as it would later be called) was based on the belief that cooperation was better than competition for economic growth and social progress. In this model the government fulfilled a key role. It was dirigiste in the creation of the caring state and a safe hydraulic structure, coordinating in the rise of the welfare state and a follower in the emergence of the consumer society.

Another characteristic of the economy was the dominance of six multinationals: Philips, Shell, DSM, Akzo, Unilever and Hoogovens. They played a big part in the growth of the economy and employment. They also shared in the ambitions for well-being in the Netherlands. Philips, for example, invested in housing, schooling, health care, recreation and culture for its employees.

Characteristic of this economy dominated by multinationals was the complexity and international character of the chains of production and consumption. The chains were long (they included multiple production processes), became denser (numerous production processes co-existed within one organisation) or differentiated (chains split up into multiple chains). For example, biochemical research at Unilever led to the interchangeability of vegetable and animal oils and fats. Margarine could be produced from whale blubber, fish oil or palm oil. Chains of raw materials fragmented into different basic products (commodities) that were traded as bulk goods on the international market. This changed the position of food processing firms. Where it once was a purveyor of added value in a chain of foodstuffs, it now became a hub in a network. This enabled them to acquire important positions of power in the diverse international flows of products. These developments transported sustainability issues around the production of food across the national borders. While in the Netherlands 'not a penny too much' was paid for margarine, in the Congo vast swaths of the jungle was cleared for palm oil plantations in order to satisfy the demand for oil 'on the global market.'

The linear nature of the economy was also an important determinant of sustainability. Materials were acquired at one location, separated and processed at other places, and consumed at a third location, after which they degenerated into waste products or emissions. This had already long been the case for the use of turf as fossil fuel in the Netherlands. Coal, oil and natural gas made no difference here. The combustion of fossil fuels was by definition linear. With the increasing use of

\footnotetext{
${ }^{18}$ Bouwens and Dankers, Tussen concurrentie en concentratie. Belangenorganisaties, kartels, fusies en overnames, 158-159.
} 
artificial fertiliser and the flushing of faecal matter through sewers at the end of the nineteenth century a similar linear chain developed for food. In the course of the twentieth century other substances like paper, glass and plastics were added to the list. At the start of the chain, the linear economy dotted the landscape with empty gravel pits, marl pits and closed mines, and at the end with huge garbage mounds.

The period was marked by a short effort, born of necessity, to retreat back to the circular economy. During the Second World War disrupted supplies of raw materials encouraged re-use and substitution. Wood replaced energy suppliers like coal and gas. Soap was fabricated from bones. Paper, textiles, glass, metals, rubber, hair and many other materials were collected in order to be recycled.

\subsection{The Monitor for 1970: Development of Well-being and Sustainability}

How can we judge the culmination of this period - around 1970 - in terms of wellbeing and sustainability? In this section we will address this question from three perspectives (Table 16.1). The perspective of 1910: to what extent was the societal agenda of the first decades of the twentieth century realized? The perspective of 1970: which elements were at the time praised by politics and policy, what were the contemporary concerns and what was the agenda for the future? Finally, we look at the developments from a present-day perspective. How do we judge the results of the period 1910-1970 by today's norms?

\subsubsection{Perspective 1910: The Agenda at the Turn of the Century}

The further suppression of extreme poverty (securing the vital necessities: food, clothing and housing) had been supplemented as a social-economic agenda with concerns about the quality of food, housing, health and labour. Around 1970 the aims of 1910 had been largely realised. Extreme poverty had been abolished. Much had been accomplished in regard to food quality, housing quality, public health and working conditions. The population had also profited from increased economic and material welfare. People lived longer and were healthier, had jobs and time for themselves.

These aims were achieved by means of the large-scale employment of domestic and foreign natural capital. Increased exploitation of natural capital had been an explicit goal around 1900. 'Wastelands' had been reclaimed and land had been 
Table 16.1 Dashboard well-being and sustainability 'here and now' in 1970 from the perspectives of 1910, 1970 and a present-day perspective

\begin{tabular}{|c|c|c|c|c|c|c|}
\hline \multicolumn{7}{|c|}{ Dashboard well-being 'here and now' } \\
\hline Theme & Indicator & Unit & 1970 & \begin{tabular}{|l|} 
Perspective \\
1910
\end{tabular} & \begin{tabular}{|l|} 
Perspective \\
1970
\end{tabular} & $\begin{array}{l}\text { Present day } \\
\text { perspective }\end{array}$ \\
\hline Population & & $\begin{array}{l}\text { million } \\
\text { inhabitants }\end{array}$ & 13,0 & & & \\
\hline \multicolumn{7}{|c|}{ Material Welfare and Well-being } \\
\hline \multirow[t]{3}{*}{$\begin{array}{l}\text { Consumption, } \\
\text { income }\end{array}$} & $\begin{array}{l}\text { Consumptive } \\
\text { Expenditures per } \\
\text { capita / constant prices }\end{array}$ & $\begin{array}{l}\text { index } \\
(1850=100)\end{array}$ & 340 & + & + & + \\
\hline & $\begin{array}{l}\text { Income inequality, } \\
\text { general }\end{array}$ & $\begin{array}{l}\text { Gini coefficient } \\
0-1\end{array}$ & 0,36 & + & + & + \\
\hline & $\begin{array}{l}\text { Gender income } \\
\text { inequality }\end{array}$ & $\begin{array}{l}\% \text { difference } \\
\text { hourly wage } \\
\mathrm{M} / \mathrm{F}\end{array}$ & $29 \%$ & + & $\mathrm{O}$ & - \\
\hline $\begin{array}{l}\text { Subjective } \\
\text { well-being }\end{array}$ & Satisfaction with life & score $0-10$ & 7,4 & $?$ & + & + \\
\hline \multicolumn{7}{|c|}{ Personal Characteristics } \\
\hline Health & Life expectancy & years & 75 & + & + & + \\
\hline Nutrition & Height & $\mathrm{cm}$ & 182 & + & + & + \\
\hline \multirow[t]{2}{*}{ Housing } & Housing quality & $\%$ slums & 6 & + & - & - \\
\hline & Public water supply & $\mathrm{m}^{3} /$ capita & 109 & + & + & + \\
\hline Physical Safety & Murder victims & $\begin{array}{l}\text { Number per } \\
100.000 \\
\text { inhabitants. }\end{array}$ & 0,7 & - & - & - \\
\hline Labour & Unemployment & $\%$ workforce. & 1,6 & + & + & + \\
\hline Education & Level of Education & years & 9 & + & + & + \\
\hline Free time & Free time & hours / week. & 47,9 & + & + & + \\
\hline \multicolumn{7}{|c|}{ Natural Environment } \\
\hline Biodiversity & MSA & $\begin{array}{l}\% \text { original } \\
\text { biodiversity }\end{array}$ & 66 & + & - & - \\
\hline \multirow[t]{2}{*}{ Air quality } & $\mathrm{SO}_{2}$ & $\mathrm{~kg} \mathrm{SO}_{2} /$ capita & 21 & + & - & - \\
\hline & $\begin{array}{l}\text { Greenhouse gas } \\
\text { emissions }\end{array}$ & ton $\mathrm{CO}_{2}$ /capita & 10,1 & + & + & - \\
\hline Water quality & Public water supply & $\mathrm{m}^{3} /$ capita & 109 & + & - & - \\
\hline \multicolumn{7}{|c|}{ Institutional environment } \\
\hline Trust & Generalised trust & $\begin{array}{l}\% \text { population } \\
\text { with adequate } \\
\text { trust }\end{array}$ & $?$ & - & - & - \\
\hline $\begin{array}{l}\text { Political } \\
\text { Institutions }\end{array}$ & Democracy & $\begin{array}{l}\text { Democracy- } \\
\text { index 0-100 }\end{array}$ & 39 & + & + & + \\
\hline
\end{tabular}


Table 16.1 (continued)

\begin{tabular}{|c|c|c|c|c|c|c|}
\hline \multicolumn{7}{|c|}{ Dashboard well-being 'later' } \\
\hline \begin{tabular}{|l|} 
Theme \\
\end{tabular} & Indicator & Unit & 1970 & $\begin{array}{l}\text { Perspective } \\
1910\end{array}$ & \begin{tabular}{|l} 
Perspective \\
1970
\end{tabular} & $\begin{array}{l}\text { Present day } \\
\text { perspective }\end{array}$ \\
\hline \multicolumn{7}{|l|}{ Natural Capital } \\
\hline Energy & Energy consumption & TJ/capita & 0,16 & + & - & - \\
\hline $\begin{array}{l}\text { Non-fossil } \\
\text { fuels }\end{array}$ & $\begin{array}{l}\text { Domestic } \\
\text { consumption }\end{array}$ & ton/capita & 9,4 & + & - & - \\
\hline Biodiversity & MSA & $\begin{array}{l}\% \text { original } \\
\text { biodiversity }\end{array}$ & 66 & + & - & - \\
\hline \multirow[t]{2}{*}{ Air quality } & $\mathrm{SO}_{2}$ emissions & $\mathrm{kg} \mathrm{SO}_{2} /$ capita & 21 & + & - & - \\
\hline & $\begin{array}{l}\text { Greenhouse gas } \\
\text { emissions }\end{array}$ & ton $\mathrm{CO}_{2} /$ capita & 10,1 & + & - & - \\
\hline Water & Public water supply & $\mathrm{m}^{3} /$ capita & 109 & + & + & - \\
\hline \multicolumn{7}{|c|}{ Economic Capital: } \\
\hline Physical capital & $\begin{array}{l}\text { Economic capital } \\
\text { stock/capita }\end{array}$ & $\begin{array}{l}\text { index } \\
(1850=100)\end{array}$ & 518 & + & + & + \\
\hline $\begin{array}{l}\text { Financial } \\
\text { capital }\end{array}$ & Gross national debt & $\%$ gdp & 48 & + & + & + \\
\hline Knowledge & $\begin{array}{l}\text { Supply of knowledge } \\
\text { capital }\end{array}$ & $\begin{array}{l}\text { index } \\
(2010=100)\end{array}$ & 30 & + & + & + \\
\hline \multicolumn{7}{|c|}{ Human Capital: } \\
\hline Health & Life expectancy & years & 75 & + & + & + \\
\hline Labour & Unemployment & $\%$ workforce & 1,6 & + & + & + \\
\hline \begin{tabular}{l|} 
Educational \\
level
\end{tabular} & Schooling & years & 9 & + & + & + \\
\hline \multicolumn{7}{|c|}{ Social Capital: } \\
\hline \begin{tabular}{|l|l} 
Trust \\
\end{tabular} & Generalised trust & $\begin{array}{l}\% \text { population } \\
\text { with adequate } \\
\text { trust }\end{array}$ & $?$ & - & - & - \\
\hline $\begin{array}{l}\text { Political } \\
\text { institutions }\end{array}$ & Democracy & $\begin{array}{l}\text { democracy } \\
\text { index } 0-100\end{array}$ & 38,5 & + & + & + \\
\hline
\end{tabular}

\section{Dashboard well-being 'elsewhere'}

\begin{tabular}{|c|c|c|c|c|c|c|}
\hline Theme & Indicator & Unit & 1970 & \begin{tabular}{|l|} 
Perspective \\
1910
\end{tabular} & \begin{tabular}{|l|} 
Perspective \\
1970
\end{tabular} & $\begin{array}{l}\text { Present day } \\
\text { perspective }\end{array}$ \\
\hline \multicolumn{7}{|c|}{ Material Welfare } \\
\hline $\begin{array}{l}\text { Consumption, } \\
\text { income }\end{array}$ & Development aid & $\%$ gdp & 0,6 & + & $\mathrm{O}$ & $\mathrm{O}$ \\
\hline \multicolumn{7}{|c|}{ Natural capital } \\
\hline Natural capital & $\begin{array}{l}\text { Import of raw } \\
\text { materials }\end{array}$ & ton/capita & 8,6 & + & $\mathrm{O}$ & - \\
\hline
\end{tabular}

\section{Legend}

\begin{tabular}{|c|l|}
\hline+ & Not problematic or not problematized \\
\hline- & Generally acknowledged as problematic \\
\hline O & Under discussion: different opinions about the scale and nature of the problems \\
\hline$?$ & Unknown \\
\hline
\end{tabular}

Source: See note 24 of Chap. 2 
wrested from the sea. Coal, salt and marl were mined and sand, gravel, oil and gas extracted from the subsoil. Imported metal ores, crude oil, grains, natural oils and fats were incorporated into Dutch production processes. Increasing exploitation was accompanied by increasing energy consumption. The political and policy establishment of 1910 would have looked at these indicators with great satisfaction. That would also have been the case for the indicators of economic and human capital and of democratic quality, while they would have been concerned about the political turbulence around 1970 (social capital) - as they were about political struggles in their own time. Politics and policy in those days had no goals for biodiversity and emissions, so that little can be said from this perspective about the declining biodiversity and increasing emissions. On the other hand the political elite of 1910 would have deeply regretted the changed relationship to the former colonies (development aid) and would have rejoiced at the increased exploitation of foreign natural capital (import raw materials).

\subsubsection{Perspective 1970: Environmental Problems in New Babylon}

These developments were viewed in an entirely different light from the perspective of 1970 . Up to the end of the 1950s the Netherlands, a country faithful to traditions and customs, had been maintained by a system of pillarisation. A few individuals foresaw a great change. Automation and robotisation would create a New Babylon, as Cobra artist Constant Nieuwenhuys proclaimed in 1959. The future would see the rise of 'homo ludens,' the creative, playful human. ${ }^{19}$

Ten years later these intimations of change had become the fertile soil for diverse forms of protest against authority, industrialisation and modernisation. Compared to surrounding countries, the turnaround was gradual and without extreme violence, either on the side of the opposition or on that of the authorities. ${ }^{20}$ Confessional, socialist and liberal parties remained at the centre of power, but cloaked with a new 'progressive' élan. And they had to co-exist with new political parties and movements. Around 1970, the Pacificist-Socialist Party (1957), the Farmers' Party (1963), Provo (1965), the Democrats ‘66 (1966), the Political Party Radicals (1968), the Kabouter (Gnome) Movement (1970) and other political movements attempted to change the existing political and institutional structures on the basis of their own social visions.

The renewed traditional parties and most of the new ones shared one big concern, namely concern about the natural environment and the exploitation of natural capi-

\footnotetext{
${ }^{19} \mathrm{~J}$. van der Lans and H. Vuijsje, Lage landen, hoge sprongen: Nederland in de twintigste eeuw (Wormer 2003), 185.

${ }^{20}$ J.C. Kennedy, Nieuw Babylon in aanbouw: Nederland in de jaren zestig (Amsterdam 1995), 9-22.
} 
tal. The worries focused originally on changes in the landscape (among other things, biodiversity), the use of materials (e.g. the growing mountains of waste), water pollution (especially surface waters) and air pollution (particularly the emission of sulphur dioxide). The exhaustibility of raw materials and energy sources soon surfaced as a major social problem. Other aspects like the safety of nuclear energy and the emission of greenhouse gases were not yet on the agenda.

An important theme at the time was certainly the global opposition between rich and poor. It was essential to support the poor countries. Between 1965 and 1975 the Dutch contribution rose from one million to nearly one billion euros. This made the Netherlands, along with Norway, one of the most generous countries in the world. ${ }^{21}$

\subsubsection{The View from 2015-1970 as a Critical Watershed}

From a present-day perspective the construction of the caring and welfare state was a great achievement. The Netherlands had become a prosperous country, in which a quality of life had been achieved that pretty much answered to present-day standards. Both the general and material aspects of well-being were at a high level. To be sure, the wage inequality between men and women that prevailed in 1970 would have raised eybrows in the present day. Average life expectancy had increased and was still climbing. The numerous victims of traffic accidents, the large numbers of smokers and other health risks would no longer be acceptable. On the other hand, the low incidence of crime would be something to long for again. The housing shortage was nearly solved and big investments in this field continued. And the internal arrangements and furnishings of homes increasingly approached presentday standards for heating and sanitation. The spacious homes built in the 1970s are still popular nearly 50 years later. The level of unemployment was lower than what is presently considered acceptable. Access to and quality of education was high.

At the same time a present-day observer would share the big concerns about the natural environment and natural capital. In 1970 biodiversity was in better shape than it is at present. And even then it was anything but hopeful. Salmon and trout had disappeared from rivers and streams due to pollution of surface water. Emissions of poisonous effluents in the Rotterdam Harbour area threatened flora and fauna in the Wadden Sea. Farmers sought to eliminate every kind of weed and insect that threatened their yields. Reclamations and land consolidation created an ever more monotonous landscape. In 1970 natural ecosystems and biodiversity were under extreme pressure.

Air pollution due to sulphur dioxide emssions was significant, but diminishing thanks to the use of filters, de-sulphurisation of fuels and the transition from coal to gas. New insights into air quality would lead to new concerns about public health and air quality. Soot particles, nitrous oxides and fine dust replaced sulphur

\footnotetext{
${ }^{21}$ Kennedy, Nieuw Babylon in aanbouw, 73-74.
} 
dioxide as an indicator of air quality. In 1970 there was as yet little concern about climate change; that debate surfaced only in the 1980s after which it began to draw increasing attention. Due to the increased use of energy and materials the emission of 'climate gases' increased. $\mathrm{CO}_{2}$ emissions at the time were about $21 \%$ higher than the current 2020 European goal of 8.6 tons per inhabitant. In the domain of natural capital and the human environment the period around 1970 was indeed a watershed.

\subsubsection{The 1960s as the Great Transformation}

In the prologue to this book we wrote about the great transformation in well-being: the Netherlands increased the quality of life of its population, but at the cost of depleting Dutch and foreign natural capital. That transformation can be traced over the course of the 1960s. In this part of the book it has been analysed for the three large material flows - the bio and the mineral and fossil sub-soil assets - and from the perspective of the four institutions - government, economy, the societal midfield and research. And yet the issue still demands a generic explanation. That explanation will have to account for a remarkable phenomenon. The biggest issue in the career of well-being in the Netherlands, namely the problematic quality of life of the population, was solved at the outset of the 1960s with the establishment of the 'caring-state.' But the big problems with natural capital and the natural environment arose after that period. As statistics of various material flows make amply clear, the exploitation of natural capital accelerated in the course of the 1960s. This was accompanied by an accelerated growth in emissions that soon reached levels exceeding present-day norms. What is the origin of this 'de-railing?' Did it have to do with the demands that the 'caring state' had to make on natural capital in order to guarantee a certain quality of life for a growing population? Was it a consequence of the welfare state? Could it be attributed to fundamental changes in the economic structure, among other things due to the discovery of the Groningen natural gas field? In the epilogue to this book, when we review the entire period from 1850 to 2010, we will return to these questions. The issue raises another insistent question. At the end of the 1960s contemporaries were aware of the 'de-railing' that was taking place. Around 1970 a critical boundary in sustainability had been passed in various respects. Old and new groups in the societal mid-field signalled problems around the over-exploitation of natural capital and the pollution of the environment and manoeuvred them onto the societal agenda. Despite this, the situation would get worse before it got better. The problems proved nearly intractable. Why was it so difficult to create a sustainable society? That will be the most important question of the next part. 


\section{Literature}

Blom, J.C.H. (1989). Crisis, bezetting en herstel: Tien studies over Nederland, 1930-1950. Rotterdam: Nijgh \& Van Ditmar Universitair,

Bouwens, B. and J. Dankers (2010). Tussen concurrentie en concentratie: Belangenorganisaties, kartels, fusies en overnames. Bedrifsleven in Nederland in de twintigste eeuw. Amsterdam: Boom.

Bruins, B. (1967, 5 augustus). 'We veranderen de wereld... met chemische vergiften'. Het vrije volk: democratisch-socialistisch dagblad, p. 4.

Davids, M., H.W. Lintsen, and A. van Rooij (2013). Innovatie en kennisinfrastructuur: Vele wegen naar vernieuwing. Vol. 5. Bedrijfsleven in Nederland in de Twintigste Eeuw. Amsterdam: Boom.

Howarth, S and J. Jonker (2007). 'Powering the hydrocarbon revolution, 1939-1973'. In J.L. van Zanden, J. Jonker, S. Howarth and K. Sluyterman (eds.) A history of Royal Dutch Shell. New York: Oxford University Press.

Huguenot van der Linden, A. (29-07-1967). 'Landbouw legt het af tegen groei van wereldbevolking als gewas niet wordt beschermd' in De Telegraaf.

Kennedy, J.C. (1995). Nieuw Babylon in aanbouw: Nederland in de jaren zestig. Amsterdam: Boom.

Lans, J. van der and H. Vuijsje (2003). Lage landen, hoge sprongen: Nederland in de twintigste eeuw. Wormer: Inmerc.

Lintsen, H.W. (2005). Made in Holland: Een techniekgeschiedenis van Nederland [1800-2000]. Zutphen: Walburg Pers.

Lintsen, H.W. (eds.) (2013). Tachtig jaar TNO. Delft: TNO.

Oldenziel, R. (2001). 'Het ontstaan van het moderne huishouden: toevalstreffers en valse starts, 1890-1918'. In J.W. Schot, H.W. Lintsen, A. Rip and A.A. Albert de la Bruhèze (eds.), Techniek in Nederland in de twintigste eeuw - Deel IV. Zutphen: Walburg Pers.

Rooy, P. de (2014). Ons stipje op de waereldkaart: De politieke cultuur van modern Nederland. Amsterdam: Wereldbibliotheek.

Schuyt, K. and E. Taverne (2000). 1950: Welvaart in zwart wit. Den Haag: Sdu Uitgevers.

Zanden, J.L. van and R.T. Griffiths (1989). Economische geschiedenis van Nederland in de twintigste eeuw. Utrecht: Het Spectrum.

Open Access This chapter is licensed under the terms of the Creative Commons Attribution 4.0 International License (http://creativecommons.org/licenses/by/4.0/), which permits use, sharing, adaptation, distribution and reproduction in any medium or format, as long as you give appropriate credit to the original author(s) and the source, provide a link to the Creative Commons license and indicate if changes were made.

The images or other third party material in this chapter are included in the chapter's Creative Commons license, unless indicated otherwise in a credit line to the material. If material is not included in the chapter's Creative Commons license and your intended use is not permitted by statutory regulation or exceeds the permitted use, you will need to obtain permission directly from the copyright holder.

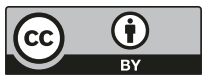

